\title{
New constraints on the age and evolution of the Wishbone Ridge, southwest Pacific Cretaceous microplates, and Zealandia-West
}

\section{Antarctica breakup}

\author{
N. Mortimer Institute of Geological and Nuclear Sciences, Private Bag 1930, Dunedin, New Zealand \\ K. Hoernle \\ F. Hauff \\ IFM-GEOMAR Leibniz Institute for Marine Sciences, Wischhofstrasse 1-3, D-24148 Kiel, Germany \\ J.M. Palin Geology Department, University of Otago, P.O. Box 56, Dunedin, New Zealand \\ W.J. Dunlap Research School of Earth Sciences, Australian National University, Canberra, Australia \\ R. Werner Tethys Geoconsulting GmbH, Wischhofstrasse 1-3, D-24148 Kiel, Germany \\ K. Faure Institute of Geological and Nuclear Sciences, P.O. Box 30368, Lower Hutt, New Zealand
}

\section{ABSTRACT}

We present analytical results from four dredge locations across the eastern Zealandia continental margin and adjacent ocean crust. The 115 Ma dacites dredged from the West Wishbone Ridge (WWR) are isotopically primitive, weakly adakitic, slabderived lavas. The $97 \mathrm{Ma}$ A-type granites and a basalt from the easternmost Chatham Rise enlarge the known area of postsubduction Gondwana magmatism. Amphibolite-grade schists from a fault block south of the Chatham Rise provide a critical bridge between the Zealandia and West Antarctica belts of JurassicCretaceous accretionary prism rocks. The new recognition of the WWR as a remnant of a $\mathbf{1 1 5}$ Ma intraoceanic subduction system means that previous hypotheses of the WWR as a fracture zone or spreading ridge require modification. The dacite ages constrain the start of Osbourn Trough spreading, which caused breakup of the Hikurangi-Manihiki igneous plateau, to before 115 Ma. We speculate that, after $115 \mathrm{Ma}$, the WWR was rifted by an intraoceanic spreading center that developed along its southeast side. Impingement of this spreading center against the Gondwana margin led to widespread 95-100 Ma postsubduction magmatism, variable lithospheric stretching, and ultimately continental splitting of Zealandia and West Antarctica across basement trends.

Keywords: Cretaceous, southwest Pacific, Gondwana, dating, geochemistry, tectonics.

\section{INTRODUCTION}

The Wishbone Ridge is an enigmatic 2000-km-long forked gravity feature in the southwest Pacific Ocean (Fig. 1). It has variously been interpreted as an extinct spreading center (Luyendyk, 1995) or an intraoceanic fracture zone or zones across which Osbourn Trough spreading was dextrally offset to another ridge system (Billen and Stock, 2000; Sutherland and Hollis, 2001), or to a trench at the Gondwana margin (Larter et al., 2002). These tectonic models are not well constrained by magnetic anomaly data because all of the abyssal oceanic crust adjacent to the Wishbone Ridge formed in the Cretaceous normal superchron (83-118 Ma). The Hikurangi Plateau, a Cretaceous large igneous province (LIP), is another major feature of the southwest $\mathrm{Pa}$ cific Ocean (Wood and Davy, 1994; Mortimer and Parkinson, 1996; Hoernle et al., 2004). The inferred collision of the Hikurangi Plateau with the Gondwana continental margin (Chatham Rise) has been used in a variety of speculative tectonic models, particularly those relating to the cessation of subduction and subsequent Zealandia-West Antarctica rifting (e.g., Mortimer, 2004, and references therein).

In order to provide critical geological constraints for these models, basement rocks were sampled at four sites in a transect across the eastern Zealandia continent-ocean margin during the SO168 cruise of the R/V Sonne (December 2002-January 2003). The radiometric age and petrological results that we present here are the first samples recovered from these remote yet major continental and oceanic features. Our results have implications for Gondwana and southwest Pacific tectonics, and shed light on a variety of general geological issues such as formation of intraoceanic subduction zones, inheritance of geochemical characteristics of lavas from old orogens, and lithospheric controls on continental breakup.

\section{GEOCHEMICAL AND AGE RESULTS}

Information about the regional setting, bathymetry, sample descriptions, and analytical methods are in Data Repository Appendix DR1. ${ }^{1}$ Sample locations and analytical data are in Data Repository Appendices DR2-DR7. The largely monolithologic nature of the four dredges, along with broken Mn-crusted surfaces, rules out an ice-rafted origin for the rocks at each site.

\section{West Wishbone Ridge}

Siliceous lavas and associated sedimentary rocks were dredged from three sites (dredges 54, 55, and 56) within $15 \mathrm{~km}$ of each other on the $40^{\circ}$ slopes of a 1-km-high southeast-facing scarp of a fault block on the Wishbone Ridge (Appendix DR1, Fig. DR1; see footnote 1). Midpoint dredge coordinates of dredge 55 are lat $40^{\circ} 45.05^{\prime} \mathrm{S}$, long $169^{\circ} 49.87^{\prime} \mathrm{W}$ (water depth $2930 \mathrm{~m}$ ). The lavas are medium-K, metaluminous plagioclase + biotite + oxide \pm hornblende \pm augite \pm quartz porphyritic dacites. On a primitive mantle-normalized multielement diagram (Fig. 2), it is clear that the dacites are very depleted compared with typical siliceous igneous rocks. The troughs at the high field strength elements (HFSE: $\mathrm{Nb}, \mathrm{Ta}, \mathrm{Ti}$ ) and the peaks at large ion lithophile elements (LILE: Rb, U, K, and $\mathrm{Sr}$ ) in the multielement patterns are not observed in mid-ocean ridge and intraplate oceanic volcanic rocks, but are characteristic of subduction-zone volcanic rocks (see also Fig. 3A). The dacites have slightly elevated $\mathrm{Sr} / \mathrm{Y}$ (8-34) and $\mathrm{La} / \mathrm{Yb}$, low heavy rare earth element (REE) and $\mathrm{Y}$ contents (Fig. 2), and high $\mathrm{Sm} / \mathrm{Yb}$ compared to most arc volcanic rocks. While the extreme $\mathrm{Sr} / \mathrm{Y}(>40)$ of adakites (Drummond and Defant, 1990) is not present, they have no negative Eu anomalies, and it is possible that the Wishbone dacites have mildly adakitic affinities. The U-Pb zircon ages of two Wishbone lavas and a volcaniclastic sandstone have pooled means of $115 \pm 1 \mathrm{Ma}(2 \sigma$, mean square of weighted deviates 3.1; Fig. $3 \mathrm{~B}$ ), and one of the lavas has an Ar-Ar hornblende age of $113 \pm 4$ Ma (Appendix DR1, Fig. DR2A). The lack of inherited substantially older zircon grains, and the mid-oceanic-ridge basalt-like initial $\mathrm{Sr}$ $\mathrm{Nd}-\mathrm{Pb}$ isotopic ratios (Figs. 3B, 3C; Appendix 1, Fig. DR2B) indicate

${ }^{1}$ GSA Data Repository item 2006035, Appendices DR1-DR7, sample and analytical data including Fig. DR1 (bathymetry of dredge sites) and Fig. DR2 (argon spectra and $\mathrm{Pb}$ isotope diagrams), is available online at www.geosociety.org/pubs/ft2006.htm, or on request from editing@geosociety. org or Documents Secretary, GSA, P.O. Box 9140, Boulder, CO 80301-9140, USA. 


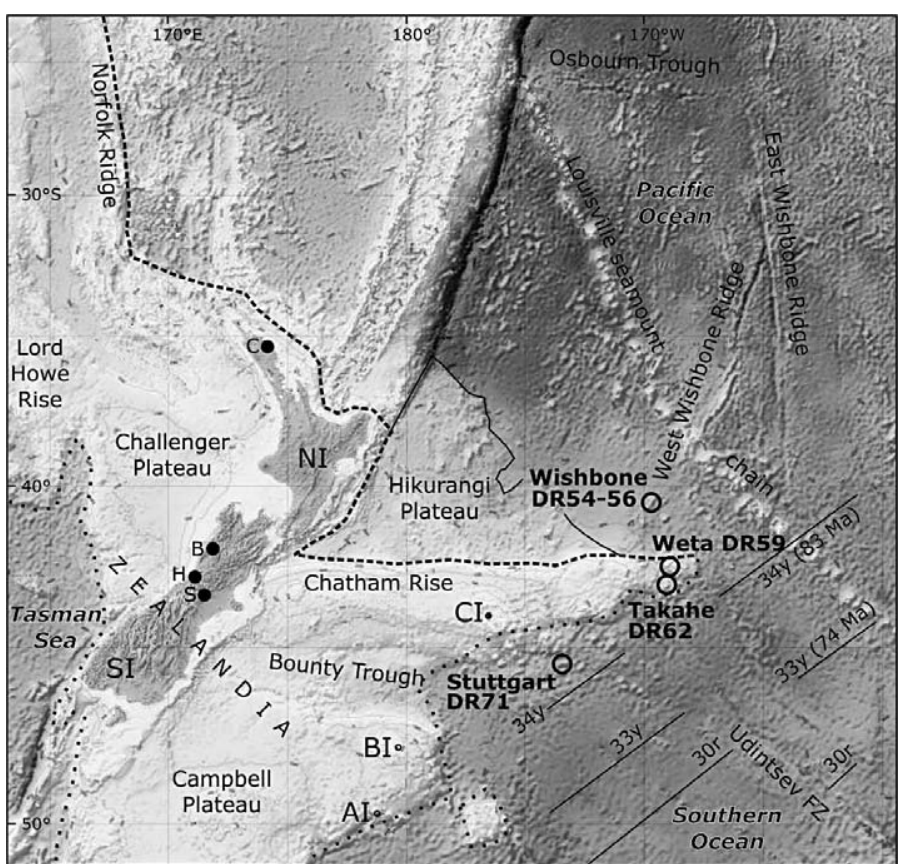

Figure 1. Map showing locations of four S0168 dredge sites (DR; black circles) in southwest Pacific Ocean. Dashed line is inferred Mesozoic convergent margin (modified by Cenozoic tectonics north of Chatham Rise). Dotted lines are ca. 85 Ma rift margins. Black dots are onland New Zealand postsubduction granite-rhyolite suites (ca. 90-100 Ma). B-Berlins Porphyry; S-Mount Somers; H-Hohonu Batholith, C-Mount Camel Complex. Base map is from Stagpoole (2002), magnetic anomalies are simplified from Larter et al. (2002). NI-North Island; SI-South Island; $\mathrm{Cl}-$ Chatham Islands; $\mathrm{BI}-$ Bounty Islands; AI-Antipodes Island; FZ-fracture zone.

a local, intraoceanic source for the Wishbone lavas. The $\delta^{18} \mathrm{O}_{\text {magma }}$ value calculated from a measurement on clinopyroxene is $+5.4 \%$ (Appendices DR1, DR4) and suggests that there was no significant oxygen contribution from marine carbonates, pelagic clays, or weathered or hydrothermally altered oceanic crust.

\section{Easternmost Chatham Rise: Takahe and Weta Seamounts}

The only rock types recovered at Takahe (dredge 62 , lat $43^{\circ} 3.71^{\prime} \mathrm{S}$, long $168^{\circ} 45.23^{\prime} \mathrm{W}$, depth $2770 \mathrm{~m}$ ) were porphyritic biotite leucogranite (some with drusy cavities, indicating high-level intrusion), with biotite leucogranodiorites as xenoliths. The U-Pb zircon ages of samples of host rock and xenoliths indicate indistinguishable ages of $97 \mathrm{Ma}$ (Fig. 3B). The Takahe geochemistry is distinctly different from the Wishbone lavas. The $\mathrm{SiO}_{2}$ and total alkalies values indicate they are weakly peraluminous and have high potassium. On the primitive mantlenormalized multi-element diagram, Takahe rocks have pronounced negative $\mathrm{Nb}$ and $\mathrm{Ta}$ anomalies and positive $\mathrm{Rb}, \mathrm{K}$, and $\mathrm{Pb}$ anomalies, characteristic of subduction-related magmatism. Compared to the Wishbone dacites, the Takahe granites are relatively enriched in all incompatible elements, except $\mathrm{Sr}, \mathrm{P}$, Ti, and $\mathrm{Eu}$ (Fig. 2), reflecting fractionation of feldspar, apatite, and Fe-Ti oxides. The lower $\mathrm{Sr} / \mathrm{Y}$, greater heavy REE contents, and deeper (more negative) Eu anomalies (Fig. 2) indicate that the Takahe granites have no adakitic characteristics; however, they have some characteristics of A-type granites (Fig. $3 \mathrm{~A})$. The initial $\mathrm{Sr}-\mathrm{Nd}-\mathrm{Pb}$ isotope ratios, moderately radiogenic $\mathrm{Sr}$ and $\mathrm{Nd}$, high ${ }^{207} \mathrm{~Pb} /{ }^{204} \mathrm{~Pb}$ at low ${ }^{206} \mathrm{~Pb} /{ }^{204} \mathrm{~Pb}$, and presence of an older zircon are consistent with the involvement of continentally derived material in the petrogenesis of the melts (Fig. 3; Appendix 1, Fig. DR2B [see footnote 1]). Collectively, these features point to distinct similarities with coeval postsubduction onland New Zealand and Antarctic suites such as Mount Somers, Berlins Porphyry, and Mount Camel Complex rhyolites and Byrd Coast granite (Figs. 1, 3A, and 4).

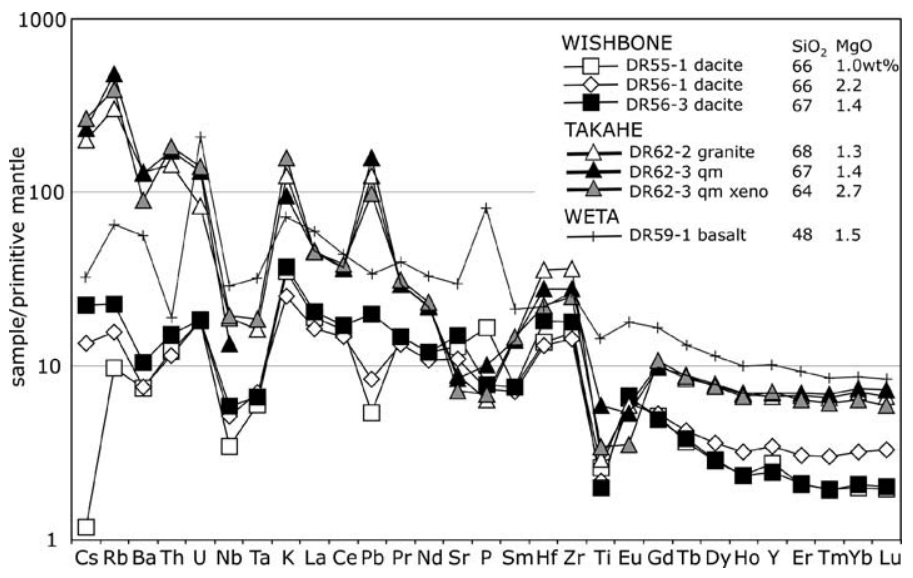

Figure 2. Primitive mantle-normalized multi-element diagram for selected Wishbone, Takahe, and Weta lavas; qm-quartz monzonite; xeno-xenolith.

These suites have mixed I- and A-type affinities; their Nb anomalies are considered to have been inherited from their source areas and/or host rocks (Ewart et al., 1992; Weaver et al., 1994; Waight et al., 1998; Tappenden, 2003).

The bathymetry of the Weta dredge site shows a flat-topped northnortheast-trending volcanic or tectonic ridge. Dredge 59, on the north side of a guyot (lat $42^{\circ} 16.85^{\prime} \mathrm{S}$, long $168^{\circ} 51.03^{\prime} \mathrm{W}$, depth $2671 \mathrm{~m}$ ), yielded an altered (and undated) olivine basalt. Despite some phosphorite contamination (Fig. 2), the primitive mantle-normalized multielement diagram is similar to an alkali olivine basalt, but shows a small subduction-like $\mathrm{Nb}$ and $\mathrm{Ta}$ anomaly.

\section{Southern Ocean Rifted Margin: Stuttgart Seamount}

Recovery of banded greenish-gray oligoclase + albite + quartz + biotite + muscovite + ilmenite \pm garnet \pm hornblende \pm epidote \pm titanite schists at dredge 71 on Stuttgart seamount, $380 \mathrm{~km}$ eastsoutheast of the Chatham Islands (lat $45^{\circ} 29.32^{\prime} \mathrm{S}$, long $173^{\circ} 15.67^{\prime} \mathrm{W}$, depth 3950 m; Fig. 1; Appendix DR1), along with swath mapping, reveal a faulted block of continental crust surrounded by Southern Ocean abyssal plain on all sides. Ar-Ar step heating of two white micas and one hornblende separate from the Stuttgart schists did not yield statistical plateaus (Appendix DR1, Fig. DR2). However, both mica samples behave similarly, in that most of the gas gives ages of 140 150 Ma. Jurassic-Cretaceous white mica ages are typical of the onland Haast Schist of New Zealand (e.g., Adams and Robinson, 1977; Gray and Foster, 2004), including schist basement on the Chatham Islands (Fig. 1).

The mafic volcaniclastic protolith of the Stuttgart schists and the high metamorphic grade suggest a match with the Caples terrane-Haast Schist belt of onland New Zealand.

\section{DISCUSSION}

West Wishbone Ridge: Intraoceanic Subduction at 115 Ma

The Wishbone lavas are unlike any siliceous igneous rocks found in ocean crust formed at mid-ocean ridges or in intraplate oceanic volcanic settings (e.g., East Pacific Rise, Iceland, and Galapagos), but are similar to those in intraoceanic subduction zone settings (e.g., Smith et al., 2003). It seems reasonable that the location and subductionrelated, weakly adakitic chemistry of the dacites, the igneous provenance of the sandstones, the cataclastic deformation, and bathymetric evidence for faulting (Appendix DR1; see footnote 1) are all intimately related to the origin and evolution of the 1800-m-high WWR. We see no way to explain the HFSE anomalies except through slab dewatering, a petrologic process that accompanies plate convergence (Tatsumi and Eggins, 1995). 

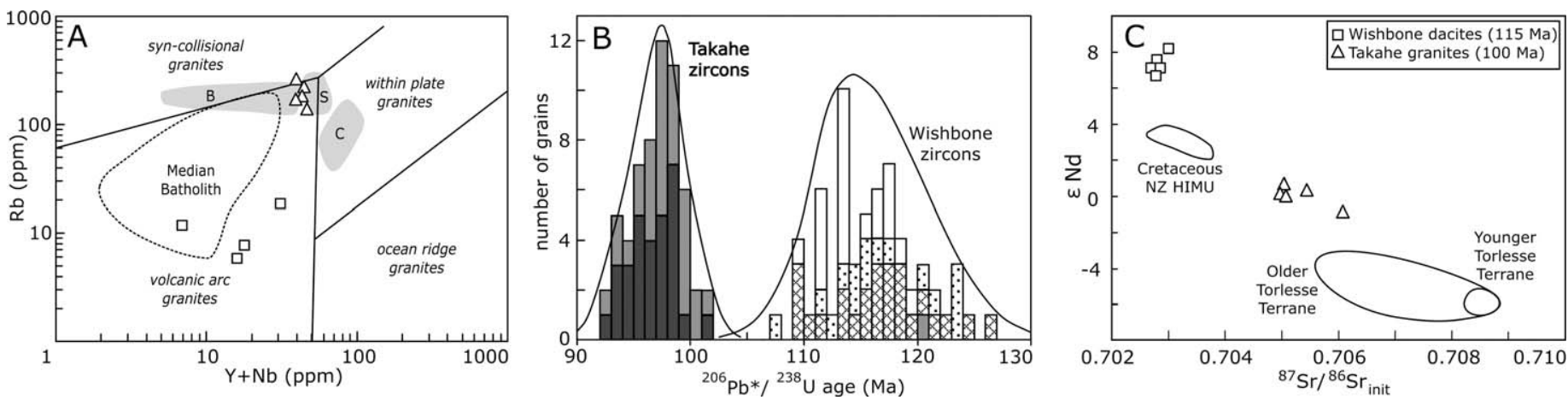

Figure 3. A: Comparison of Wishbone (squares), Takahe (triangles), and onland New Zealand syn-subduction Median Batholith and postsubduction suites on granite trace element diagram of Whalen et al. (1987); B-Berlins Porphyry; S-Mount Somers; C-Mount Camel Complex (see Fig. 1). Reference field data are from Palmer et al. (1995), Mortimer et al. (1999), and unpublished analyses of Institute of Geological and Nuclear Sciences. B: Zircon age histograms and cumulative probability curves from two Takahe (gray) and three Wishbone (other patterns) samples; all data shown; shading and patterns correspond to different analyzed samples. Typical two sigma errors on individual grain ages are \pm 3 m.y. (Takahe) and \pm 5 m.y. (Wishbone). C: Sr-Nd isotope correlation diagram. NZ HIMU-New Zealand high $\mu$ lavas.

The WWR probably developed as a major pre-115 Ma intraoceanic fracture zone, across which highly oblique convergence proceeded to the stage where dehydration-induced melting of peridotitic and/or eclogitic material took place. The presence of lavas effectively at the fracture zone may suggest a subvertically dipping slab, but the WWR geometry may have been severely modified by later rifting (Fig. 4). The WWR probably developed to a more advanced stage than the present-day Hjort-Macquarie-Puysegur Ridge (Reay and Parkinson, 1997; Meckel et al., 2003), but further sampling is needed to assess the age range, degree of maturity, and polarity of our putative "Wishbone Arc." The Wishbone zircon data hint at the existence of older volcanism (Fig. 3B). Given the proximity of the Hikurangi Plateau to the Wishbone dredge site, it is possible that the thermal pulse that

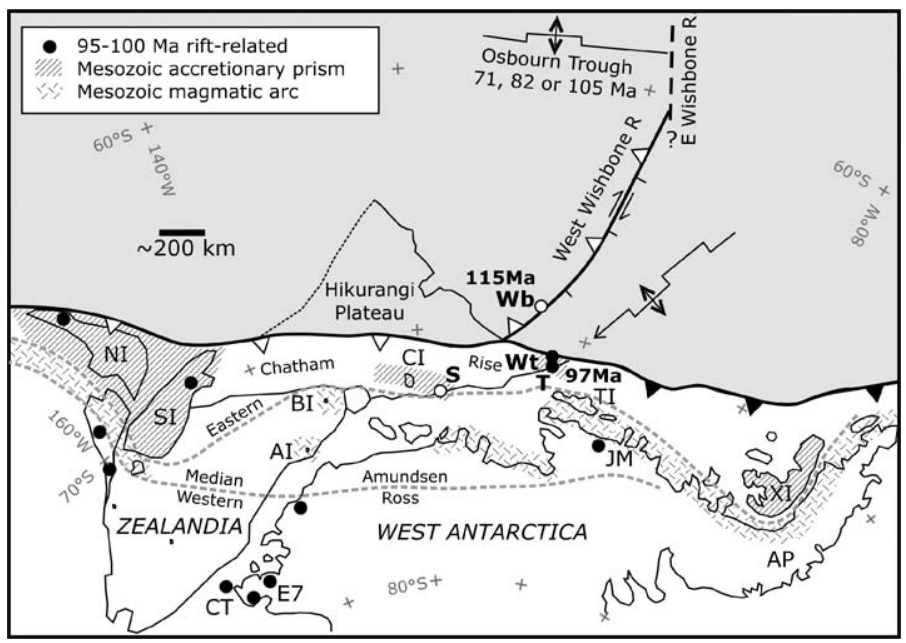

Figure 4. Cretaceous (ca. $90 \mathrm{Ma}$ ) tectonic reconstruction showing West Wishbone Ridge as pre-115 Ma fracture zone, $115 \mathrm{Ma}$ arc, and post-115 Ma rift feature (sense of strike- slip motion and arc polarity are speculative). Takahe and Weta are most trenchward postsubduction igneous suites on Gondwana margin and Stuttgart is part of Mesozoic accretionary prism belt. Modern coastlines are projected on $90 \mathrm{Ma}$ reconstruction from Eagles et al. (2004, their Fig. 4). Oceanic plate features (gray) are shown schematically. Sites of active and former subduction are shown by black and white triangles, respectively. Geology is from Maslanyj et al. (1991), Bradshaw et al. (1997), Pankhurst et al. (1993), and Mortimer (2004). R-ridge; WbWishbone; Wt-Weta; T-Takahe; S-Mt. Stuttgart; AP-Antarctic Peninsula; XI-Alexander Island; TI-Thurston Island; JM-Jones Mountains; E7-Edward VII Peninsula; CT-Colbeck Trough; other abbreviations as in Figure 1. generated the LIP ( $\geq 118-93 \mathrm{Ma}$; Hoernle et al., 2005) was also partly responsible for generating the Wishbone Ridge melts and/or for initiating the subduction (e.g., Niu et al., 2003).

\section{Osbourn Trough Spreading}

Billen and Stock (2000) identified the Osbourn Trough as a remnant spreading center that would have split the formerly adjacent Hikurangi and Manihiki Plateaus. Our $115 \mathrm{Ma}$ age from the Wishbone Ridge provides the first geological constraint on the time of initiation of that spreading (Fig. 4). Normal oceanic crust seems to abut the northwest side of the WWR and the Hikurangi Plateau and would have to be older than the $115 \mathrm{Ma}$ age of the lavas erupted onto it. This means that the LIPs must have been moving apart from each other very early in their eruptive history.

\section{WWR: Post-115 Ma Rifting?}

Lyons et al. (2000) modeled a break in lithospheric elastic thickness at the WWR, consistent with older crust to the west and younger crust to the east. Figure 1 shows that anomaly $34 \mathrm{y}$ ( $83 \mathrm{Ma}$ ) is 300 $500 \mathrm{~km}$ southeast of the WWR and that older crust might be expected between it and the WWR. We suggest that the southeast side of the WWR was rifted by a newly initiated $<115 \mathrm{Ma}$ intraoceanic spreading center (possibly part of the Pacific-Phoenix or Pacific-Charcot system of Larter et al., 2002) and that the angle between the WWR and anomaly $34 \mathrm{y}$ indicates southwest propagation and/or asymmetric spreading of that center. Simple extrapolation of the $33 y-34 y$ half-spreading rate $(39 \mathrm{~mm} / \mathrm{yr}$ ) back against the WWR gives a possible rifting age of 92 $98 \mathrm{Ma}$.

\section{Tests of Southwest Pacific Tectonic Models}

Our Wishbone Ridge results permit us to test and reconcile a number of earlier, apparently disparate, tectonic models of the WWR and environs. The main new ideas we propose are that the WWR is a $115 \mathrm{Ma}$ intraoceanic arc and, more speculatively, that its evolution before and after 115 Ma was dominantly as a strike-slip fault and rift edge feature, respectively. Billen and Stock (2000) and Larter et al. (2002) interpreted the WWR as a fracture zone: we agree, but only for the interval before $115 \mathrm{Ma}$. Sutherland and Hollis (2001) predicted convergence across the WWR in response to Hikurangi PlateauGondwana margin collision: our interpretations also require convergence by ca. $115 \mathrm{Ma}$, and of sufficient amount to cause arc magmatism. Luyendyk (1995) proposed that the WWR was a remnant spreading center, but the dredging of arc rocks does not support this. Davy (2004) suggested reactivation of the WWR as an extensional feature, a hypothesis with which we agree. 


\section{From Subduction to Extension at the Gondwana Margin}

Elements of the convergent Mesozoic orogen can be traced, albeit discontinuously, for more than $2000 \mathrm{~km}$ from the Antarctic Peninsula to New Zealand (Fig. 4). The Stuttgart schists and the single inherited 121 Ma zircon of the Takahe granite confirm that the Mesozoic accretionary prism is present between the Chatham Islands and Alexander Island.

Did collision of the Hikurangi Plateau with the Chatham Rise cause subduction to stop? The 115 Ma subduction-related dacite eruptions on the WWR are plausibly a response to oceanic microplate breakup, but it does not follow that the lavas date the timing of Hikurangi Plateau-Chatham Rise collision. Our discovery of the intraoceanic Wishbone Arc introduces another Early Cretaceous volcanotectonic system that could have (1) collided with the Gondwana margin independently of the Hikurangi Plateau (e.g., Muir et al., 1995) and/or (2) been an exotic source of Early Cretaceous detrital zircons to the accretionary prism (e.g., Cawood et al., 1999).

The $97 \mathrm{Ma}$ Takahe granites, and the Weta basalt, are the closest examples to the paleotrench of 90-100 Ma magmatism thus far discovered. Correlative widespread A-type granites (Fig. 4) suggest that a slab window had opened up by $95-100 \mathrm{Ma}$, i.e., convergence had ceased beneath Zealandia. Sutherland and Hollis (2001) noted the need for dextral strike-slip motion along this Cretaceous continent-ocean margin, so the Hikurangi Plateau, West Wishbone arc, and the slab window could all have widened and/or migrated progressively eastward along the Zealandia margin.

The southwest projection and/or propagation of the putative younger than $115 \mathrm{Ma}$ ridge system southeast of the WWR is oriented at an angle to the continent-ocean margin high enough to have initiated normal faulting across the basement trends and possibly was the principal control on Zealandia and West Antarctica splitting where and when they did (Fig. 4).

\section{ACKNOWLEDGMENTS}

We thank the captain and crew of the R/V Sonne, Neville Orr, John Simes, Ray Soong, Charlotte Allen, Lorraine Paterson, John Hunt, and Dieter GarbeSchönberg for logistical, technical, and analytical support. Irradiations were facilitated by the Australian Institute for Nuclear Science and Engineering and provided by the Australian Nuclear Science and Technology Organisation. We have had useful discussions with Rick Herzer, Bryan Davy, Bryan Storey, Rupert Sutherland, Karsten Gohl, Jan Grobys, Bryan Davy, and Steve Weaver. Graeme Eagles, Bryan Storey, and Timothy Meckel provided helpful manuscript reviews. We thank the German Ministry for Education and Research (BMBF) for funding the Sonne cruise and the $\mathrm{BMBF}$ and the New Zealand Public Good Science Fund for funding the analytical work. Institute of Geological and Nuclear Sciences contribution 3483.

\section{REFERENCES CITED}

Adams, C.J.D., and Robinson, P., 1977, Potassium-argon ages of schists from Chatham Island, New Zealand plateau, southwest Pacific: New Zealand Journal of Geology and Geophysics, v. 20, p. 287-301.

Billen, M.I., and Stock, J., 2000, Morphology and origin of the Osbourn Trough: Journal of Geophysical Research, v. 105, p. 13,481-13,489, doi: 10.1029/ 2000JB900035.

Bradshaw, J.D., Pankhurst, R.J., Weaver, S.D., Storey, B.C., Muir, R.J., and Ireland, T.R., 1997, New Zealand superterranes recognized in Marie Byrd Land and Thurston Island, in Ricci, C.A., ed., The Antarctic region: processes and evolution: Siena, Italy, Terra Antarctica Publications, p. 429-436.

Cawood, P.A., Nemchin, A.A., Leverenz, A., Saeed, A., and Ballance, P.F., 1999, U/ $\mathrm{Pb}$ dating of detrital zircons: Implications for the provenance record of Gondwana margin terranes: Geological Society of America Bulletin, v. 111, p. 1107-1119, doi: 10.1130/0016-7606(1999)111<1107:UPDODZ > 2.3.CO;2

Davy, B., 2004, The Wishbone Ridge: Eos (Transactions, American Geophysical Union), v. 85, abs. T41A-1159.

Drummond, M.S., and Defant, M.J., 1990, A model for trondhjemite-tonalite-dacite genesis and crustal growth via slab melting: Archean to modern comparisons: Journal of Geophysical Research, v. 95, p. 21,503-21,521.

Eagles, G., Gohl, K., and Larter, R.D., 2004, High-resolution animated tectonic reconstruction of the South Pacific and West Antarctic margin: Geochemistry, Geophysics, Geosystems, v. 5, p.Q07002, doi: 10.1029/2003GC 000657, doi: 10.1029/2003GC000657.

Ewart, A., Schon, R.W., and Chappell, B.W., 1992, The Cretaceous volcanic-plutonic province of the central Queensland (Australia) coast-A rift related "calcalkaline" province: Royal Society of Edinburgh Transactions, Earth Sciences, v. 83 , p. 327-345.

Gray, D.R., and Foster, D.A., 2004, ${ }^{40} \mathrm{Ar} /{ }^{39} \mathrm{Ar}$ thermochronologic constraints on deformation, metamorphism and cooling/exhumation of a Mesozoic accretionary wedge, Otago Schist, New Zealand: Tectonophysics, v. 385, p. 181-210, doi: 10.1016/j.tecto.2004.05.001.

Hoernle, K., Hauff, F., van den Bogaard, P., Werner, R., and Mortimer, N., 2005, The Hikurangi oceanic plateau: Another large piece of the largest volcanic event on Earth: Goldschmidt Conference Abstracts, Moscow, Idaho, USA, May 21-25 Geochimica et Cosmochimica Acta, v. 69, supplement 1, p. A96.

Hoernle, K., Hauff, F., Werner, R., and Mortimer, N., 2004, New insights into the origin and evolution of the Hikurangi oceanic plateau: Eos (Transactions, American Geophysical Union), v. 85, p. 401-405.

Larter, R.D., Cunningham, A.P., Barker, P.F., Gohl, K., and Nitsche, F.O., 2002, Tectonic evolution of the Pacific margin of Antarctica 1. Late Cretaceous tectonic reconstructions: Journal of Geophysical Research, v. 107, no. B12, p. 2345, doi: $10.1029 / 2000 \mathrm{JB} 000052$.

Luyendyk, B.P., 1995, Hypothesis for Cretaceous rifting of East Gondwana caused by subducted slab capture: Geology, v. 23, p. 373-376, doi: 10.1130/00917613(1995)023<0373:HFCROE $>2.3$.CO;2

Lyons, S.N., Sandwell, D.T., and Smith, W.H.F., 2000, Three-dimensional estimation of elastic thickness under the Louisville Ridge: Journal of Geophysical Research, v. 105, p. 13,239-13,252, doi: 10.1029/2000JB900065.

Maslanyj, M.P., Garrett, S.W., Johnson, A.C., Renner, R.G.B., and Smith, A.M., 1991 Aeromagnetic anomaly map of West Antarctica (Weddell Sea sector). BAS GEOMAP Series, sheet 2: Cambridge, British Antarctic Survey, scale $1: 2,500,000,37 \mathrm{p}$

Meckel, T.A., Coffin, M.L., Mosher, S., Symonds, P., Bernadel, G., and Mann, P., 2003, Underthrusting at the Hjort trench, Australian-Pacific plate boundary: Incipient subduction?: Geochemistry, Geophysics, Geosystems, v. 4, p. 1099 doi: 10.1029/2002GC000498.

Mortimer, N., 2004, New Zealand's geological foundations: Gondwana Research, v. 7 , p. $261-272$

Mortimer, N., and Parkinson, D., 1996, Hikurangi Plateau: A Cretaceous large igneous province in the southwest Pacific Ocean: Journal of Geophysical Research, v. 101, p. 687-696, doi: 10.1029/95JB03037.

Mortimer, N., Gans, P.B., Calvert, A., and Walker, N.W., 1999, Geology and thermochronometry of the east edge of the Median Batholith (Median Tectonic Zone): A new perspective on Permian to Cretaceous crustal growth of New Zealand: The Island Arc, v. 8, p. 404-425, doi: 10.1046/j.14401738.1999.00249.x.

Muir, R.J., Weaver, S.D., Bradshaw, J.D., Eby, G.N., and Evans, J.A., 1995, The Cretaceous Separation Point batholith, New Zealand: Granitoid magmas formed by melting of mafic lithosphere: Geological Society [London] Journal, v. 152, p. 689-701.

Niu, Y., O'Hara, M.J., and Pearce, J.A., 2003, Consequence of lateral compositional buoyancy contrast within the lithosphere: A petrological perspective: Journal of Petrology, v. 44, p. 851-866, doi: 10.1093/petrology/44.5.851.

Palmer, K., Mortimer, N., Nathan, S., Isaac, M.J., Field, B.D., Sircombe, K.N., Black, P.M., Bush, S., and Orr, N.W., 1995, Chemical and petrographic analyses of some New Zealand Paleozoic-Mesozoic metasedimentary and igneous rocks: Institute of Geological and Nuclear Sciences Science Report 95/16, 37 p.

Pankhurst, R.J., Millar, I.L., Grunow, A.M., and Storey, B.C., 1993, The pre-Cenozoic magmatic history of the Thurston Island crustal block, West Antarctica: Journal of Geophysical Research, v. 98, p. 11,835-11,849.

Reay, A.E., and Parkinson, D., 1997, Adakites from Solander Island, New Zealand: New Zealand Journal of Geology and Geophysics, v. 40, p. 121-126.

Smith, I.E.M., Worthington, T.J., Stewart, R.B., Price, R.C., and Gamble, J.A., 2003 Felsic volcanism in the Kermadec arc, SW Pacific: Crustal recycling in an oceanic setting, in Larter, R.D. and Leat, P.T., eds., Intra-oceanic subduction systems: Tectonic and magmatic processes: London, Geological Society of London Special Publication 219, p. 99-118.

Stagpoole, V.M., 2002, The New Zealand continent, version 1.0: Lower Hutt, New Zealand, Institute of Geological and Nuclear Sciences Geophysical Map GPM 15 , scale $1: 7,500,000$.

Sutherland, R., and Hollis, C., 2001, Cretaceous demise of the Moa plate and strikeslip motion at the Gondwana margin: Geology, v. 29, p. 279-282, doi: 10.1130/ 0091-7613(2001)029<0279:CDOTMP $>2.0$. CO 2 .

Tappenden, V.E., 2003, Magmatic response to the evolving New Zealand margin of Gondwana during the mid-Late Cretaceous [Ph.D. thesis]: Christchurch, University of Canterbury, $260 \mathrm{p}$.

Tatsumi, Y., and Eggins, S., 1995, Subduction zone magmatism: Boston, Massachusetts, Blackwell Publishing, $211 \mathrm{p}$

Waight, T.E., Weaver, S.D., Muir, R.J., Maas, R., and Eby, G.N., 1998, The Hohonu Batholith of North Westland, New Zealand: Granitoid compositions controlled by source $\mathrm{H}_{2} \mathrm{O}$ contents and generated during tectonic transition: Contributions to Mineralogy and Petrology, v. 130, p. 225-239, doi: $10.1007 / \mathrm{s} 004100050362$

Weaver, S.D., Storey, B.C., Pankhurst, R.J., Mukasa, S.B., DiVenere, V.J., and Bradshaw, J.D., 1994, Antarctica-New Zealand rifting and Marie Byrd Land lithospheric magmatism linked to ridge subduction and mantle plume activity: Geology, v. 22, p. 811-814, doi: 10.1130/0091-7613(1994)022<0811: ANZRAM $>2.3 . \mathrm{CO} ; 2$.

Whalen, J.B., Currie, K.L., and Chappell, B.W., 1987, A-type granites: Geochemical characteristics, discrimination and petrogenesis: Contributions to Mineralogy and Petrology, v. 95, p. 407-419, doi: 10.1007/BF00402202.

Wood, R.A., and Davy, B., 1994, The Hikurangi Plateau: Marine Geology, v. 118 p. 153-173, doi: $10.1016 / 0025-3227(94) 90118-X$

Manuscript received 14 August 2005

Revised manuscript received 8 November 2005

Manuscript accepted 16 November 2005

Printed in USA 